\title{
Helicase SKI2W
}

National Cancer Institute

\section{Source}

National Cancer Institute. Helicase SKI2W. NCI Thesaurus. Code C29971.

Helicase SKI2W (1246 aa, 138 kDa) is encoded by the human SKIV2L gene. This protein is involved in RNA metabolism. 